Syntax Literate : Jurnal Ilmiah Indonesia p-ISSN: 2541-0849 e-ISSN : 2548-1398

Vol. 5 No. 3 Maret 2020

\title{
FAKTOR YANG BERHUBUNGAN DENGAN PENGGUNAAN ALAT KONTRASEPSI IUD (INTRA UTERINE DEVICE) PADA AKSEPTOR MKJP (METODE KONTRASEPSI JANGKA PANJANG) DI WILAYAH KERJA UPTD PUSKESMAS SUKAHAJI KABUPATEN MAJALENGKA TAHUN 2019
}

\section{Lia Natalia}

Sekolah Tinggi Ilmu Kesehatan (STIKes) YPIB Majalengka

Email: lianataliahaning@gmail.com

\section{Abstract}

Based on the inter-sensus population survey (Supas) result of 2015, the Indonesian population in 2019 about 266,91 million people. People who used IUD in Sukahaji PHC were 5.6\% of 2017. The purpose of this study was to determine the factors associated to the use of IUD (Intra Uterine Device) contraceptive method. The study design was analytic study with case control approach. IUD acceptors were the cases with a number of 128 respondents. Controls were implants and MOW acceptors with the number of 128 respondents, taken by purposive sampling. Research instrument used is questionnaire. The data analysis was conducted in univariate, bivariate and multivariate.The study results showed that the factors associated significantly to the use of IUD contraceptive method were knowledge $(p=0.001)$, education $(p=0.001)$, employment $(p=0.001)$, parity $(p=0.001)$, age $(p=0.001)$, socio-economic $\quad(p=0.001)$, culture $(p=0.001)$, service rates $(p=0.026)$, the information by Family Planning field personnel $(p=$ 0.002$,$) , service providers (p=0.001)$ and husband support $(p=0.001)$, while the availability of tools $(p=0.617)$ and the availability of man personel $(p=0.142)$ were not associated to the use of IUD contraceptive method. The results of multivariate analysis, the most dominant variable associated to IUD contraceptive method was husband support $(p=0.001, O R=5.638)$. With the study results, it is expected to perform continual improvement of family planning services quality by providing counseling which involves husbands, community leaders and religious leaders.

Keywords : Family Planning, IUD, Acceptors, Rural

\footnotetext{
Abstrak

Berdasarkan hasil survey penduduk antar sensus (Supas) 2015 jumlah penduduk Indonesia pada tahun 2019 sekitar 266,91 juta jiwa. Jumlah yang menggunakan IUD di Puskesmas Sukahaji sebesar 4,80\% pada tahun 2018. Tujuan penelitian ini untuk mengetahui faktor yang berhubungan dengan penggunaan alat kontrasepsi IUD (Intra Uterine Device). Rancangan penelitian ini adalah penelitian analitik dengan pendekatan case control. Kasus adalah akseptor KB IUD dengan jumlah 128 responden. Kontrol adalah akseptor KB implan dan MOW dengan jumlah 128 responden, cara pengambilan sampel dengan purposive sampling. Instrumen yang digunakan adalah angket. Analisis yang dilakukan meliputi univariat, bivariat dan
} 
multivariat. Hasil penelitian didapatkan faktor yang berhubungan bermakna dengan penggunaan alat kontrasepsi IUD yaitu pengetahuan $(p=0,001)$, pendidikan $(p=$ $0,001)$, pekerjaan $(p=0,001)$, paritas $(p=0,001)$, umur $(p=0,001)$, sosial ekonomi $(p=0,001)$, budaya $(p=0,001)$, tarif pelayanan $(p=0,026)$, informasi oleh petugas lapangan $\mathrm{KB}(p=0,002)$, penyedia pelayanan $(p=0,001)$ dan dukungan suami $(p$ $=0,001)$, dan faktor yang tidak berhubungan adalah ketersediaan alat $(p=0,617)$ dan ketersediaan tenaga $(p=0,142)$. Hasil analisis multivariat, variabel yang paling dominan berhubungan dengan alat kontrasepsi IUD adalah dukungan suami $(\mathrm{p}=0.001, \mathrm{OR}=5,638)$. Dengan adanya hasil penelitian ini diharapkan terus kualitas pelayanan $\mathrm{KB}$ dengan memberikan penyuluhan melibatkan suami, tokoh masyarakat dan tokoh agama.

Kata kunci : Keluarga Berencana, IUD, akseptor, perdesaan

\section{Pendahuluan}

Masalah penduduk merupakan salah satu masalah yang dihadapi oleh negara berkembang, termasuk Indonesia. Salah satu masalah kependudukan yang dihadapi Indonesia adalah laju pertumbuhan penduduk yang cukup tinggi. Sensus penduduk tahun 2018 menunjukkan jumlah penduduk Indonesia sekitar 265.02 juta jumlah perempuan sebesar 133,87 jiwa penduduk. Tetapi jumlah ini mengalami penurunan jumlah penduduk dari tahun 2014 (252, 12 juta jiwa) hingga tahun 2018. Jumlah Penduduk di Jawa Barat merupakan jumlah penduduk paling banyak di Indonesia sebanyak 48,68 juta jiwa. Hal ini terlihat jelas bahwa jumlah penduduk dari tahun ke tahun selalu mengalami kenaikan (Kemenkes RI, 2018).

Sasaran pokok pembangunan KKB di dalam RPJMN 2015-2019 adalah menurunnya laju pertumbuhan penduduk, menurunya angka kelahiran total/total fertility rate (TFR) dan meningkatnya angka keikutsertaan ber-KB/Contraseptive Prevalence Rate (CPR). Pada tahun 2-15, jumlah peserta KB baru adalah 6,41 juta dibandingkan target 6, 84 juta. Sementara tahun 2016 adalah 6,66 juta dari target 6,96 juta. Untuk mencapai target yang ditetapkan itu diperlukan kerja keras. Pemerintah juga memberikan kebijakan untuk meningkatkan Metode Kontrasepsi Jangka Panjang (MKJP) pada akseptor dan tren penggunaan MKJP mengalami kenaikan yaitu pada SDKI 2012 sebesar 18,30 persen, SDKI 2015 sebesar 21,30 persen dan SDKI 2016 sebesar 21,60. Walaupun tidak mengalami peningkatan secara signifikan akan tetapi berhasil mencapai target yang telah ditetapkan. (Bappenas, 2017).

Mencermati pemakaian MKJP selama beberapa periode survei menunjukkan kecenderungan menurun. Baru pada tahun 2012-2016 pencapaian MKJP relatif tetap. Penurunan MKJP tampaknya bersumber dari pemakaian metode IUD (Intra Uterine Device) yang terus menurun, sementara pencapaian MOP (Meja Operasi Wanita), MOW (Meja Operasi Wanita) relatif tetap, dan pencapaian implant yang mengalami fluktuasi selama periode tersebut (BKKBN, 2017).

IUD (non hormonal) merupakan salah satu jenis alat kontrasepsi jangka panjang yang ideal dalam upaya mencegah kehamilan. Keuntungan pemakaian IUD yakni hanya memerlukan satu kali pemasangan untuk jangka waktu yang lama dengan biaya yang 
relatif murah. IUD juga merupakan alat kontrasepsi yang aman, karena tidak mempunyai pengaruh sistemik yang beredar keseluruh tubuh, tidak mempengaruhi produksi ASI dan kesuburan cepat kembali setelah IUD lepas. Selain memiliki banyak keuntungan, IUD juga memiliki efek samping, antara lain perdarahan, rasa nyeri atau kejang perut, dan gangguan pada suami ketika berhubungan namun sejauh ini masih dapat diatasi (Wulandari, 2008).

Program Keluarga Berencana Nasional mempunyai kontribusi penting dalam upaya meningkatkan kualitas penduduk di Indonesia (Suyanti, 2016). Hasil pendataan keluarga tahun 2017 menunjukkan bahwa secara nasional jumlah peserta KB Aktif tercatat sebanyak 23.606.218 peserta, dan jumlah Pasangan Usia Subur (PUS) sebanyak 37.338.265 peserta, sehingga tingkat kesertaan menggunakan KB dari seluruh PUS sebesar 63,22\%. Yang menggunakan KB MKJP tahun 2017 hanya sebesar 17, 45\% dan yang menggunakan Non MKJP sebesar 82,55\% dan Provinsi Jawa Barat menempati urutan ke-12 dilihat dari tingkat prevalensi PUS peserta KB (BKKBN, 2017).

Berdasarkan data Kemenkes RI menunjukkan bahwa pada tahun 2017 di Indonesia peserta KB aktif dengan penggunaan IUD sebesar 397.996 (7,75\%), MOW sebesar 194.636 (3,41\%), MOP sebesar 39.843 (0,70\%), kondom sebesar 65.390 $(1,14 \%)$, implan sebesar $471.979(8,26 \%)$, suntikan 4,128.115 (48,56\%), pil sebesar $993.255(7,39 \%)$.

Di Jawa Barat menurut (Kemenkes RI, 2017) jumlah PUS sebesar 1.545.324 dan jumlah PUS Peserta KB aktif sebesar 1.058.887 dan yang menggunakan IUD 85.534 (8,17\%), MOW 3.319 (36.138\%), MOP 5.785 (0,55\%), Kondom 7.655 (0,72\%), implant 60.194 (5,68\%), suntikan 650.390 (5,68\%), pil 209.027 (19,74\%).

Di Kabupaten Majalengka tahun 2017 jumlah pasangan usia subur sebanyak 265.288 orang sedangkan jumlah peserta KB Baru sebanyak $4.807(1,81 \%)$ dan Peserta KB aktif sebanyak 210.258. dari peserta KB Aktif yang menggunakan KB MKJP sebanyak $36.588(16,85 \%)$ dengan peserta IUD sebanyak 10.458 (4,82\%), MOP sebanyak 2,205 (1,02\%), MOW sebanyak 10.579 (4,87\%), Implan sebanyak 13,345 $(6,15 \%)$. Sedangkan yang menggunakan Non MKJP sebanyak $176.471(83,93 \%)$ dengan peserta KB suntik sebanyak 145.431 (66,98\%), pil sebanyak 32.720 (15,07\%), kondom sebanyak $2.394(1,10 \%)$, dan tidak ada yang menggunakan obat vagina. (Dinas Kesehatan Kabupaten Majalengka, 2018).

Rendahnya jumlah peserta KB IUD disebabkan karena beberapa faktor seperti : 1) ketidaktahuan peserta tentang Keuntungan KB IUD. Dimana pengetahuan tentang alat kontrasepsi merupakan pertimbangan dalam menentukan metode kontrasepsi yang akan digunakan, 2) kualitas pelayanan $\mathrm{KB}$, dilihat dari segi ketersediaan alat kontrasepsi, ketersediaan tenaga yang terlatih dan kemampuan medis teknik petugas pelayanan kesehatan, 3) Adanya hambatan dukungan dari suami dalam pemakaian IUD. 4) Adanya niat yang timbul dari adanya sikap yang didasarkan pada kepercayaan (budaya), norma-norma di masyarakat dan norma pokok yang ada dalam lingkungan. Salah satu norma yang dianut masyarakat adalah pemasangan IUD yang dilakukan di aurat (vagina) sehingga menimbulkan perasaan malu/enggan serta takut untuk 
menggunakan IUD serta banyak mitos di masyarakat tentang IUD seperti dapat mengganggu kenyamanan hubungan suami/istri, mudah terlepas jika bekerja terlalu keras, menimbulkan kemandulan dan lain sebagainya (Imbarwati, 2009).

Berdasarkan survei pendahuluan yang dilakukan peneliti di wilayah kerja UPTD Puskesmas Sukahaji Kabupaten Majalengka tahun 2018 jumlah peserta KB aktif sebanyak $3.646(86,15 \%)$ dengan akseptor yang menggunakan IUD sebesar 203 $(4,80 \%)$, MOP sebanyak 25 (0,61\%), MOW sebanyak 225 (5,32\%), Implan sebanyak $132(3,12 \%)$, suntik sebanyak 3.201 (71,38\%), pil sebanyak 579 (13,68\%), kondom sebanyak 46 (1,57\%). Pada tahun 2017 yang menggunakan IUD sebanyak $212(5,05 \%)$ dan terlihat bahwa terjadi penurunan peminat KB pada tahun 2017-2018 sebanyak 0,25\% dan UPTD Puskesmas Sukahaji merupakan UPTD dengan pencapaian IUD dengan urutan ke-17 dari 32 Puskesmas yang ada di Kabupaten Majalengka.

Berdasarkan hasil wawancara terhadap 15 responden yang berada di wilayah kerja UPTD Puskesmas Sukahaji Kabupaten Majalengka tanggal 15 Desember 2018 didapatkan bahwa yang berpengetahuan tinggi tentang IUD sebesar 3 orang (20\%), berpengetahuan rendah sebesar 12 orang $(80 \%)$, yang mendapat dukungan suami untuk menggunakan IUD sebesar 6 orang (40\%) dan tidak mendapat dukungan suami 9 orang $(60 \%)$.

Hasil penelitian (Bernadus et al., 2013) menyatakan bahwa terdapat hubungan yang bermakna antara usia, pendidikan, pengetahuan, persetujuan pasangan dan budaya dengan pemilihan IUD bagi akseptor KB, dan tidak terdapat hubungan antara pekerjaan, status ekonomi dan tarif pelayanan dengan pemilihan IUD bagi akseptor KB di Puskesmas Jailolo tahun 2013. Karena banyaknya faktor-faktor yang mempengaruhi akseptor KB dalam memilih alat kontrasepsi IUD maka variabel yang akan digunakan untuk penelitian ini adalah pengetahuan, pendidikan, pekerjaan, umur, paritas, sosial ekonomi, budaya, tarif pelayanan, ketersediaan alat, ketersediaan tenaga, informasi oleh petugas lapangan $\mathrm{KB}$, sumber pelayanan dan dukungan suami.

\section{Metode Penelitian}

Rancangan penelitian ini adalah penelitian analitik dengan pendekatan case control/kasus-kontrol. di wilayah kerja UPTD Puskesmas Sukahaji Kabupaten Majalengka dan waktu penelitian telah dilaksanakan pada bulan Januari-Maret 2015. Populasi kasus (akseptor yang menggunakan IUD) sebanyak 152 orang dan populasi kontrol (akseptor yang menggunakan MOW/Implant) sebesar 336 orang. sampel minimal yang dibutuhkan adalah sebesar 128 orang/akseptor untuk masing-masing kelompok kasus dan kontrol, sehingga jumlah keseluruhan 2 x 128 orang, yaitu 256 orang. Cara pengambilan sampel dilakukan dengan cara purposive sample. Seluruh variabel penelitian dikumpulkan dengan menggunakan kuesioner. Dalam penelitian ini peneliti menggunakan analisis univariat dengan distribusi frekuensi, analisis bivariat dengan chi square dan analisis multivariat dengan analisis regresi logistik, yaitu 
pemilihan variabel kandidat multivariat, pembuatan model faktor penentu dan penentuan akhir model.

\section{Hasil dan Pembahasan}

\section{A. Analisis Univariat}

1. Faktor Pencetus Akseptor MKJP

Tabel 1 Distribusi Frekuensi Akseptor MKJP Berdasarkan Faktor Pencetus di Wilayah Kerja UPTD Puskesmas Sukahaji Kabupaten Majalengka Tahun $2019(n=256)$

\begin{tabular}{lcc}
\hline \multicolumn{1}{c}{ Faktor Pencetus } & F & \% \\
\hline Pendidikan Tinggi & 77 & 30,1 \\
\hline Bekerja & 45 & 17,6 \\
\hline Umur <_20 dan > 35 & 85 & 33,2 \\
\hline Paritas Rendah & 92 & 35,9 \\
\hline Sosial ekonomi Tinggi & 74 & 28,9 \\
\hline $\begin{array}{l}\text { Ada Informasi dari } \\
\text { PLKB }\end{array}$ & 139 & 54,3 \\
\hline
\end{tabular}

Berdasarkan tabel 1 diketahui bahwa karakteristik faktor pemudah akseptor MKJP yang kurang dari 50\% adalah pendidikan tinggi, bekerja, umur $<20$ dan >35 tahun, paritas rendah, sosial ekonomi tinggi.

2. Faktor Pemudah Akseptor MKJP

Tabel 2 Distribusi Frekuensi Akseptor MKJP Berdasarkan Faktor

Pemudah di Wilayah Kerja UPTD Puskesmas Sukahaji Kabupaten Majalengka Tahun $2019(\mathbf{n}=\mathbf{2 5 6})$

\begin{tabular}{lcc}
\hline \multicolumn{1}{c}{ Faktor Pemudah } & F & \% \\
\hline $\begin{array}{l}\text { Tarif Pelayanan KB } \\
\text { Murah }\end{array}$ & 165 & 64,5 \\
\hline Tersedianya alat & 122 & 47,7 \\
\hline Tersedianya Tenaga & 83 & 32,4 \\
\hline $\begin{array}{l}\text { Penyedia pelayanan } \\
\text { Pemerintah }\end{array}$ & 127 & 49,6 \\
\hline
\end{tabular}

Berdasarkan tabel 2 diketahui bahwa karakteristik faktor pemudah yang kurang dari $50 \%$ adalah tersedianya alat, tersedianya tenaga dan penyedia pelayanan pemerintah.

3. Faktor Penguat (Dukungan Suami) Akseptor MKJP

Tabel 3 Distribusi Frekuensi Akseptor MKJP Berdasarkan Dukungan Suami di Wilayah Kerja UPTD Puskesmas Sukahaji Kabupaten Majalengka Tahun 2019 ( $n=256)$

\begin{tabular}{|c|c|c|}
\hline Variabel Independen & $\mathbf{f}$ & $\%$ \\
\hline - Suami menyarankan untuk ber-KB IUD & 125 & 48,8 \\
\hline $\begin{array}{l}\text { - Suami mendampingi ibu jika ibu akan dilakukan } \\
\text { pemasangan IUD. }\end{array}$ & 114 & 44,5 \\
\hline - Suami menyediakan waktu dan fasilitas jika akan dilakukan & 118 & 46,0 \\
\hline
\end{tabular}




\begin{tabular}{|c|c|c|}
\hline pemasangan KB IUD & & \\
\hline - Suami bersedia membiayai dalam pemasangan IUD & 134 & 52,3 \\
\hline $\begin{array}{l}\text { - Suami menghormati keputusan ibu dalam memilih KB yang } \\
\text { akan digunakan }\end{array}$ & 127 & 49,6 \\
\hline - Suami mengantar ibu untuk kunjungan ulang & 116 & 45,3 \\
\hline - Suami mengantar ibu untuk periksa jika ada keluhan. & 127 & 49,6 \\
\hline \multicolumn{3}{|l|}{ Dukungan Suami } \\
\hline Suami mendukung & 122 & 47,7 \\
\hline Suami Tidak Mendukung & 134 & 52,5 \\
\hline
\end{tabular}

Berdasarkan tabel 3 didapatkan bahwa kurang dari setengahnya suami mendukung terhadap penggunaan IUD di wilayah kerja UPTD Puskesmas Sukahaji.

4. Budaya Akseptor MKJP

Tabel 4 Distribusi Frekuensi Akseptor MKJP Berdasarkan Budaya di Wilayah Kerja UPTD Puskesmas Sukahaji Kabupaten Majalengka Tahun $2019(n=256)$

\begin{tabular}{|c|c|c|}
\hline Variabel Independen & $\mathbf{f}$ & $\%$ \\
\hline - Kontrasepsi IUD tidak umum digunakan & 116 & 45,3 \\
\hline - Peran suami dalam pengambilan keputusan ber-KB & 160 & 62,5 \\
\hline - Jumlah anak mempengaruhi keputusan ber-KB & 143 & 55,8 \\
\hline - Tokoh agama mengharamkan penggunaan IUD & 83 & 32,4 \\
\hline $\begin{array}{l}\text { - Pemasangan IUD tabu karena dipasang ke dalam } \\
\text { rahim }\end{array}$ & 141 & 55,0 \\
\hline $\begin{array}{l}\text { - Malu dengan cara pemasangan IUD Yang harus } \\
\text { memperlihatkan aurat (vagina) }\end{array}$ & 200 & 78,1 \\
\hline - Pemakaian IUD tidak sesuai dengan agama & 117 & 45,4 \\
\hline \multicolumn{3}{|l|}{ Budaya } \\
\hline Budaya Tidak Melarang & 139 & 54,3 \\
\hline Budaya Melarang & 117 & 45,7 \\
\hline
\end{tabular}

Berdasarkan tabel 4 didapatkan bahwa satu pertiga tokoh agama mengharamkan KB IUD di wilayah kerja UPTD Puskesmas Sukahaji.

5. Pengetahuan Akseptor MKJP

Tabel 5 Distribusi Frekuensi Akseptor MKJP Berdasarkan Pengetahuan di Wilayah Kerja UPTD Puskesmas Sukahaji Kabupaten Majalengka Tahun $2019(n=256)$

\begin{tabular}{llcc}
\hline & Variabel Independen & f & \% \\
\hline - & Pengertian IUD & 129 & 50,4 \\
\hline - & Jenis IUD & 133 & 51,9 \\
\hline - & Mekanisme Kerja IUD & 127 & 49,6 \\
\hline - & Waktu pemasangan IUD & 145 & 56,6 \\
\hline - & Efektifitas IUD & 140 & 54,6 \\
\hline - & Kontraindikasi IUD & 124 & 48,4 \\
\hline
\end{tabular}




\begin{tabular}{llcc}
\hline- & Indikasi IUD & 130 & 50,7 \\
\hline - & Keuntungan IUD & 139 & 54,3 \\
\hline$\bullet$ & Kerugian IUD & 134 & 52,3 \\
\hline - & Komplikasi IUD & 126 & 49,2 \\
\hline - & Kunjungan Ulang IUD & 136 & 53,1 \\
\hline - & Lama pemakaian IUD & 149 & 58,2 \\
\hline \multicolumn{2}{c}{ Pengetahuan } & \\
\hline$\quad$ Pengetahuan Tinggi & 135 & 52,7 \\
\hline$\quad$ Pengetahuan Rendah & 121 & 47,3 \\
\hline
\end{tabular}

Berdasarkan tabel 5.5 diketahui bahwa pertanyaan dengan jawaban yang paling tinggi adalah lama pemakaian IUD $(58,2 \%)$ sedangkan pertanyaan dengan jawaban yang paling rendah adalah pertanyaan mengenai kontraindikasi IUD $(48,4 \%)$.

\section{B. Analisis Multivariat}

1. Model Akhir

Tabel 6 Model Akhir Multivariat Regresi Logistik Penggunaan alat kontrasepsi IUD pada akseptor MKJP

\begin{tabular}{c|c|c}
\hline Variabel & p value & $\begin{array}{c}\text { OR } \\
(\mathbf{9 5 \%} \mathbf{C I})\end{array}$ \\
\hline Pengetahuan & 0,007 & $2,602(1,293-5,235)$ \\
\hline Pendidikan & 0.019 & $2,492(1,165-5,330)$ \\
\hline Pekerjaan & 0,019 & $3,259(1,214-8,749)$ \\
\hline Umur & 0,001 & $3,949(1,821-8,565)$ \\
\hline Paritas & 0,001 & $3,475(1,688-7,155)$ \\
\hline Sosial ekonomi & 0,001 & $3,632(1,662-7,936)$ \\
\hline Budaya & 0,020 & $2,238(1,136-4,4100)$ \\
\hline Informasi dari PLKB & 0,012 & $2,425(1,212-4,851)$ \\
\hline Tarif Pelayanan KB & 0,124 & $1,780(0,854-3,710)$ \\
\hline Penyedia Pelayanan & 0,111 & $1,775(0,876-3,597)$ \\
\hline Dukungan Suami & 0,001 & $5,848(2,760-12,391)$ \\
\hline
\end{tabular}

Berdasarkan tabel 6 dapat dilihat variabel yang dominan berhubungan dengan penggunaan alat kontrasepsi IUD pada akseptor MKJP adalah pengetahuan $(\mathrm{OR}=2,602)$, pendidikan $(\mathrm{OR}=2,492)$, pekerjaan $(\mathrm{OR}=3,259)$, umur $(\mathrm{OR}=3,949)$, paritas $(\mathrm{OR}=3,475)$, sosial ekonomi $(\mathrm{OR}=3,632)$, budaya $(\mathrm{OR}=2,238)$, informasi dari PLKB $(\mathrm{OR}=2,425)$, dan variabel yang paling dominan adalah dukungan suami dengan variabel perancu tarif pelayanan KB dan penyedia pelayanan dengan $\mathrm{OR}=5,848$ artinya akseptor MKJP yang mendapatkan dukungan suami mempunyai peluang 5,848 kali lebih besar menggunakan alat kontrasepsi IUD

\section{Kesimpulan}

Dari hasil penelitian didapatkan bahwa variabel yang masih kurang dari setengahnya (50\%) adalah pendidikan tinggi, bekerja, umur $<20$ dan $>35$ tahun, paritas 
rendah dan sosial ekonomi tinggi. Dari hasil uji statistik didapatkan bahwa variabel yang mempunyai hubungan bermakna dengan penggunaan alat kontrasepsi IUD adalah pengetahuan, pendidikan, pekerjaan, umur, paritas, sosial ekonomi, budaya dan informasi dari PLKB.

Dari hasil penelitian didapatkan bahwa variabel yang masih kurang dari setengahnya (50\%) adalah tersedianya alat, tersedianya tenaga dan penyedia pelayanan ke pemerintah. Hasil uji statistik didapatkan bahwa variabel yang mempunyai hubungan bermakna dengan penggunaan alat kontrasepsi IUD adalah tarif pelayanan KB dan penyedia pelayanan. Sedangkan yang tidak mempunyai hubungan yang bermakna adalah ketersediaan alat dan ketersediaan tenaga.

Dari hasil penelitian didapatkan bahwa dukungan suami masih kurang dari setengahnya (50\%). Hasil uji statistik didapatkan bahwa dukungan suami mempunyai hubungan bermakna dengan penggunaan alat kontrasepsi IUD.

Ada dua faktor yang dominan yaitu faktor pencetus dan faktor pemudah yang meliputi pengetahuan, pendidikan, pekerjaan, umur, paritas, sosial ekonomi, budaya, informasi dari PLKB dan dukungan suami. Variabel yang paling dominan berhubungan dengan penggunaan alat kontrasepsi IUD adalah dukungan suami dengan variabel perancu tarif pelayanan KB dan penyedia pelayanan dengan $\mathrm{OR}=5,848$ artinya akseptor KB yang mendapatkan dukungan suami mempunyai peluang 5,848 kali lebih besar menggunakan alat kontrasepsi IUD. 


\section{BIBLIOGRAFI}

Bernadus, J. D., Madianung, A., \& Masi, G. (2013). Faktor-faktor yang berhubungan dengan pemilihan alat kontrasepsi dalam rahim (AKDR) bagi akseptor KB di Puskesmas Jailolo. E-NERS, 1(1).

Kemenkes RI. (2017). Profil Kesehatan Indonesia 2018. Jakarta : Kemenkes RI

Kemenkes RI. (2017). Data dan Informasi Profil Kesehatan Indonesia. Jakarta : Kemenkes RI

Bappenas (2017). Evaluasi Paruh Waktu RPJMN 2015-2019. Jakarta : Bappenas

BKKBN. (2017). Pedoman Pelayanan KB dalam Jaminan Kesehatan Masyarakat. BKKBN.

BKKBN. (2017). Rencana Tindak Program Kependudukan Dan Keluarga Berencana (KKB) Kencana. BKKBN.

Imbarwati, I. (2009). Beberapa Faktor Yang Berkaitan Dengan Penggunaan KB IUD Pada Peserta Kb Non IUD Di Kecamatan Pedurungan Kota Semarang. Program Pascasarjana Universitas Diponegoro.

Kemenkes, R. I. (2013). Buletin jendela data dan informasi kesehatan. Jakarta: Pusat Data Dan Informasi Kementerian Kesehatan RI.

Suyanti, S. (2016). Diterminan Penggunaan Alat Kontrasepsi Implant Di Wilayah Kerja UPTD Puskesmas Sukahaji Kabupaten Majalengka Tahun 2015. Syntax Literate; Jurnal Ilmiah Indonesia, 1(4), 23-40.

Wulandari, T. (2008). Persepsi dan Partisipasi Masyarakat Terhadap Program Keluarga Berencana (Penelitian di Desa Panggungharjo, Kec. Sewon, Kab. Bantul). DIMENSIA: Jurnal Kajian Sosiologi, 2(1). 